\title{
The Empty Face of the Self-portrait: Time, Specter, and Event in The Fourth Portrait by Meng-Hung Chung
}

\author{
Emily ShuHui Tsai \\ National Chung Hsing University
}

\begin{abstract}
This short paper aims to critically analyze a contemporary Taiwanese film, The Fourth Portrait, directed by Meng-Hung Chung, from the perspective of Deleuzian theories. In Deleuze’s two books on cinema, the discussion of images demonstrates the entangled juxtaposition of the three levels: brain-thought, cinema-screen, and world-images that compose the cinematic consciousness. Through the interacted movement-images and time-images, the film unfolds the storyline within the aesthetic pleasure of poetic sentiment that gradually leads the audience to learn that a wandering boy, Hsiao-Hsiang, after the death of his father, has had several adventurous encounters that gradually expose the secrecy of his traumatic family: His birth mother has no decent job and his step-father has killed his own brother. This broken family has been haunted by the shared guilt and the undead memory as Derrida famously claims that hauntology precedes ontology. As the past coexists with the present, Deleuze analyzes the concept of I, with a central fracture in its pure form of the past demonstrating an ontological enigma that remains forever a secret. When the director uses the four portraits to indicate the four important events of this wandering boy, he deliberately leaves empty the fourth portrait, the self-portrait of the boy; it remains as an incomplete piece which symbolizes an enigma of his own life. It shows certain constitutive unnamable forces acting within the boy that seduces him forever to painfully misrecognize himself.
\end{abstract}

Keywords: cinematic consciousness, specter, time, images, repetition

It is as though the $I$ were fractured from one end to the other: fractured by the pure and empty form of time.

(Deleuze, Difference and Repetition, 86)

In both the East and the West, there is a strain of theoretical thought postulating that life is a series of events that repeat in difference. The haunting causality we have been seeking occurs in unknown multiplicities with ontological textures. Perhaps, tracing back toward these unnamable forces means falling into a virtual labyrinth that has no exit. For Marxist revolutionaries, social reality can be changed through a class power struggle, but there remains a certain ontological dimension that has inscribed in each individual his or her singularity of being. Even in Anti-Oedipus, which follows Nietzsche and Marx, Deleuze and Guattari would argue that the unconscious is like a factory for the desiring-machine to work on its disjunction and conjunction as the creative process of becoming; it is not a predestined daddy-mommy-me theater that forces king Oedipus eventually to get trapped in his tragic fate that fulfills Apollo's oracle. Deleuze's theories in his other books, such as The Logic of Sense and Difference and Repetition, prove that he in fact does not entirely deny this

Emily ShuHui Tsai, associate professor, Department of Foreign Languages and Literatures, National Chung Hsing University, Taiwan; main research fields: Critical Theories, Psychoanalysis, Visual Arts, and Deleuze Studies. 
ontological enigma that somehow paves the path for each individual to "master" his or her own destiny within certain limitations. Sometimes, we may wonder if there exists a metaphysical script unknowingly to direct our lives. We as the mere actors play the certain roles on the stage of life to fulfill its ontological arrangement even though we know that life, unlike films or theater performances, cannot actually provide us any chance for rehearsal. Thus, when we as the audience see movies or theater performances, we are situated in a double structure, the virtual and the actual. This structure simultaneously unfolds its multi-layered levels of difference that show not only the director's world-view, but also the characters' different modes of existence.

When the director makes his film, we bear certain questions in our mind: How has the director composed images that present events experienced by other people? And how do the leading characters confront their life issues and make a difference in their lives? This short paper focuses on a Taiwanese film, The Fourth Portrait (2010), directed by Meng-Hung Chung. From the perspective of Deleuzian theories, it brings forth the discussions on the cinematic consciousness and the different modes of life presented by the leading characters who (un)consciously create their own existence to survive hardships. Generally speaking, the Deleuzian theoretical concepts, most often applied to film emerge from two of his books, Cinema 1, on the movement-image and Cinema 2, on the time image. Indeed, on a certain level, the Deleuzian notions of images discussed in these two books suggest that cinematic images projected onto the screen are similar to the movement-images and time-images occurring in our daily thoughts, like streams of floating images and fragmented memories in the brain. According to Deleuze, our brains automatically edit these thought-images, resulting in something like the montage, the art of cutting, in the cinema. Deleuze even takes his idea further, extending it to the whole world or universe, which he conceptualizes as "metacinema" in its own right (Cinema 1, 59). Thus, these two cinema books look at images on several levels: One level occurs in the brain-screen as brain-thought; another occurs in the films as montage-editing screen images; the third occurs through the images of the world. As Deleuze and Guattari state, "The material universe, the plane of immanence, is the machine assemblage of movement-images” (59). These entangled juxtapositions of images (brain-thought, cinema-screen, and world-images) presuppose film itself and require at least two levels of analysis when it comes to the discussion of cinematic images or consciousness. One level of analysis corresponds to the director's creative arrangement of cinematic images on the screen, and the other corresponds to the actors' inner images that they project onto the world. Both kinds of images contribute to the poetic aesthetics of cinematic images.

\section{Introduction}

To better understand this discussion, a brief introduction to the film and its director is needed to piece together some fragmented images of thought into a unified picture. Meng-Hung Chung, born in Ping-Dung County in 1965, is a Taiwanese director of the so-called post New-Wave of Taiwanese Cinema. ${ }^{1}$ Known for his poetic cine-eye and creative cinematographic images, Men-Hung Chung won first place in the documentary category at the Taipei Film Festival in 2006 for his first documentary film, Doctor. This debut launched his career and other creative projects followed: Parking in 2008, ${ }^{2}$ The Fourth Portrait in 2010, ${ }^{3}$ and Soul in 2013. ${ }^{4}$ His outstanding montage-editing images have made an undeniable impression on his audiences, particularly in the case of the latter two films, which use different approaches and styles to thematize human suffering. This paper focuses on one of his films, The Fourth Portrait. 
As soon as The Fourth Portrait was released in 2010, it immediately attracted attention from the domestic audience because of its fresh perspective. Whereas New Wave Taiwanese directors primarily focused on the issue of political identity, The Fourth Portrait delves into social and psychological issues by examining the life of a fatherless child named Hsiao-Hsiang. The movie begins with the death of Hsiao-Hsiang's father. The boy's mother has already abandoned him and remarried another man, leaving Hsiao-Hsiang to wander on his own. The little boy confronts the heartbreaking events of his life with remarkable calm. In fact, viewers of the film find his calmness disturbing, taking his state of mind as an indication that he and his father had a detached relationship. After his father's death, he has no one to cook for him and nothing to eat at first; he tries to steal teachers' lunchboxes stored in the freezer at his school. At this point, a school workman becomes a pseudo-father figure to him and teaches him how to survive a life of solitude, transience, and struggle.

Of course, the audience would be curious about the meaning of the movie's title, The Fourth Portrait. What other three portraits could the title indicate? As the story develops, we come to understand that the director has used these portraits, Hsiao-Hsiang's school assignments, to describe the boy's uncertain and precarious life. The first portrait represents his dead father; the second depicts the sexual organ of his scoundrel friend, who teaches him techniques for stealing and makes Hsiao-Hsiang a partner in crime; the third shows Hsiao-Yi, Hsiao-Hsiang's missing brother, walking along the riverbank. After wandering with his scoundrel friend, Hsiao-Hsiang should be sent back to his birth mother and her new family - her new-born baby and husband (who has a low-paid job in the night market). The mother has moved from mainland China to Taiwan in search of a better life and now works at a bar. Of course, Hsiao-Hsiang's presence is a great disturbance to his mother's present family; gradually we, the audience, learn that the boy's brother died accidentally as the result of a beating by their stepfather during their mother's absence when she spent six months in jail for fraud. The ghost of Hsiao-Hsiang's brother, who never received a proper burial and therefore haunts the house and his stepfather, appears in Hsiao-Hsiang's recurring dreams, walking in silent solitude along the riverbank. The stepfather does not want Hsiao-Hsiang to divulge the family's guilty secrets. Of course, neither Hsiao-Hsiang nor his mother knows all the circumstances of Hsiao-Yi's death, but the audience learns the truth from the stepfather's touching confession to the dead child's ghost, who stands gazing at his murderer from the dark corner of the room. The confession reveals that the stepfather abused Hsiao-Yi and accidentally beat him to death when he became unhinged over his wife's absence during her incarceration.

Meanwhile, the old workman from Hsiao-Hsing's school visits him to say good-bye before returning to China after 50 years. The old man uses a metaphorical story to suggest how Hsiao-Hsiang might escape the trap of living under his stepfather's roof. In the story, frogs that have been put into a heating bottle learn how to jump out of its narrow opening to escape from it. Near the end, we observe that Hsiao-Hsiang receives another assignment at school: looking into a mirror and drawing a self-portrait, the fourth portrait. As a pipe organ plays a lyrical melody in the background, the last image we the viewers see on the screen is Hsiao-Hsiang's gazing into the mirror, confronting his own emptiness and uncertain self-identity. Eventually with struggling doubts in his mind, he closes his eyes.

\section{The Cinematic Consciousness}

Having recounted events in the storyline, this analysis now focuses on the hidden meanings behind the film's poetic imagery. My use of consciousness in this discussion is inspired not by Husserl's phenomenology or Freud's or Lacan's psychoanalysis but by Deleuze's multi-layered levels of understanding of the cinematic 
screen as the brain-thought or images. Here, the term "consciousness” refers to the audience's awareness of the fact that they are in the cinema watching a film that is being projected unto a screen. The movement-images operate as a montage, making the implicit connection between topics and ideas through continuous juxtapositions of shots, imitating how our brains construct memory. One cannot deny that these image-moving shots contribute to aesthetic effects that stimulate in the viewers certain affects. Oftentimes, the audience is enchanted by its aesthetic images that could greatly transform the boy's wandering life into a different mode of expression in existence, a fragment from a lovely poem that could dissipate affects of misery.

The film begins with the death of Hsiao-Hsiang's father. We may ask why the director chose the death of the father rather than the death of the mother for the opening scene. At first glance, one might assume that this fact is intended to point out the failure or dysfunction of all the paternal figures in the protagonist's lifebirth father, his step-father, the old workman at his school, and his scoundrel friend. In fact, just the opposite is the case: Their malfunction or impotence paves the way for a difficult but potentially heroic quest for his freedom. The little boy's unusual calmness is quite disturbing while facing such sudden events: Not every Taiwanese child left alone could behave in such a manner. It seems that he is used to living with solitude, uncertainty, and difficulties in his "innocent" ethics.

The director, Meng-Hung Chung, often uses the castaway shots tinged with dark poetic images to express indirectly how he views the boy's wandering life. The aesthetic and poetic images flowing through the lyrical and light music of a pipe organ in the background are a relief from the almost unbearable heaviness of the boy's daily misery. The aesthetic images could be regarded as the cinematic consciousness, or to be more precise, it is a creative act that renders the virtual images actualized in the mind of the director as a series of the movement-images. As an art creator, the director has to "struggle against chaos" or at least flirt with it. Deleuze and Guattari make the following statements:

The artist brings back from the chaos varieties that no longer constitute a reproduction of the sensory in the organ but set up a being of the sensory, a being of sensation, on an anorganic plane of composition that is able to restore the infinite... Art is not chaos but a composition of chaos that yields the vision or sensation, so that it constitutes, as Joyce says, a chaosmos, a composed chaos-neither foreseen nor preconceived. Art transforms chaotic variability into chaoid variety... (What Is Philosophy? 202-4)

The film director composes his work of art by means of the movement-images and the time-images projected onto the screen. Another element that is equally important to the composition of the cinematic images is light. Deleuze and Guattari write that "the set of movements, of actions and reactions is light which diffuses, which is propagated 'without resistance and without loss.' The identity of image and movement stems from the identity of matter and light. The image is movement, just as matter is light” (Cinema 1, 60). This idea completely breaks away from "the whole philosophical tradition which placed light on the side of spirit and made consciousness a beam of light which drew things out of their native darkness” (Cinema 1, 60). Deleuze follows Bergson's idea and makes his argument:

Things are luminous by themselves without anything illuminating them: All consciousness is something; it is indistinguishable from the thing, that is from the image of light... In short, it is not consciousness which is light; it is the set of images, or the light, which is consciousness, immanent to matter... We may therefore say that the plane of immanence or the plane of matter is: a set of movement-images; a collection of lines or figures of light; a series of blocs of space-time. (Cinema 1, 60-61) 
In The Fourth Portrait, Meng-Hung Chung often uses pale yellow or dim light when he presents the fixed poetic castaway shots or other movement-images; the lighting seems to suggest that the movement of cinematic consciousness flows in a rhythm and vacillates between anxious uncertainty and the possibility of the virtual creative forces that generate his own lifestyle. For example, after the father's death, an ominous mood emerges through a dimly-lit image of the window frame with a tree's leaves quivering outside and the dark clouds hanging in the sky above the mountains. An action-image of the boy returning home shifts the tone: It depicts him on the narrow road toward his home, where he encounters a dried-up snake skin on his path. Afterwards, another castaway shot, as a perception-image, focuses on the shabby house where he lives. Next, the camera delves into the interior of the house with one table and two chairs and nothing on the wall. Under the dim light, the boy looks very weary and fatigued, as if the thought of his own miserable condition leaves him on the verge of collapse. The next shot moves to a photo of the boy and his mother, both of them appearing shabby. These affection-images suggest that the past coexists with the present and that the past haunts the boy like a specter, especially after the death of the father. The boy has no one upon whom to rely, making his absent mother a symptom of his condition.

The next scene leads us to observe the poverty and neglect that characterize the boy's daily life. Forced to do the washing near the channel under a bridge, he toils at the waterside as the camera gazes upon his squatting figure; carelessly, he lets slip one piece of clothing, and it floats along the river and into the channel. He chases it, and we next cut to a shot of the recovered piece hanging on the clothes rack. As stated in Cinema 1, "Montage is the assemblage of movement-images, hence the inter-assemblage of perception-images, affection-images and action-images" (70). The perception-image could be regarded as the cinematic equivalent of direct or indirect discourse. Pasolini, quoted in Deleuze's Cinema 1, states that "the essential element of the cinematographic image corresponded neither to a direct discourse, nor to an indirect discourse, but to a free indirect discourse" (72). He adds that "the richer a language is in dialects, the more it allows free indirect discourse to flourish, or rather instead of establishing itself on an 'average level;' it is differentiated into 'low language and high language’” (73). However, Meng-Hung Chung’s film focuses on how the movement-images work and convey the embedded meanings in the cinematic consciousness. To describe this point, Pasolini would use the term, "cinematographic cogito." We the viewers see both how the boy reacts to his own living conditions and simultaneously how the cine-eye presents its own visual comment on his particular world. As Pasolini states,

... this properly cinematographic Cogito: "insistent” or "obsessive” framing, which makes the camera await the entry of a character into the frame, wait for him to do and say something and then exit, while it continues to frame the space which has once again become empty, once more leaving the scene to its pure and absolute signification as scene; "the alternation of different lenses on a same image" and "the excessive use of the zoom,” which doubles the perception of an independent aesthetic consciousness... in short, the perception-image finds its status, as free indirect subjective, from the moment that it reflects its content in a camera-consciousness which has become autonomous. (Cinema 1, 74)

Indeed, in Meng-Hung Chung's film, we experience through montage the alternation of different lenses for viewing the same image. For example, one affection-image shows the boy after the father's death going back to his dilapidated house, sitting on the chair and gazing at the void, apparently exhausted by his misfortune. Another example occurs in a scene where the boy encounters his scoundrel friend in a public toilet. The scoundrel friend has no toilet paper, and so he knocks on the wall to the neighboring toilet stall with Hsiao-Hsiang in it. The camera's gaze at the scene moves from a medium shot to a long shot from above, with 
the awkward angle on his depiction of personal space emphasizing the loss of both privacy and innocence in an immoral world.

One of the striking action-images in this film centers on Hsiao-Hsing's "para-paternal" or "pseudo-guardian" friends-the old workman at school and the young scoundrel friend. These scenes occur outdoors as the characters set off on their wandering adventure: The old workman leads the boy to the ruined or abandoned house, where they search through the objects left behind by the previous owner; the young scoundrel friend gets Hsiao-Hsiang to break into a house to steal money and other treasure. They also sneak into an elementary school and rob the younger students of their money. Both of his "pseudo-guardian" friends co-opt him into the business of "stealing" in similar, parallel scenes: In one, Hsiao-Hsiang rides around with the workman on a bicycle, and in the other, he is with the scoundrel friend on a motorcycle. During their adventurous road trips, both "mentors" give the boy advice on survival and independence. With no moral guidance from his own upbringing, Hsiao-Hsiang seems to absorb the values of these two surrogates: He is not sure that taking an object left in the ruined house should be considered "stealing," and when he breaks into a house to steal things, he acts as if he were in his own house.

The affection-images are another technique used frequently by the film's director. In addition to the four portraits with close-up shots, another impressive affection-image likely arouses affects of fear in the viewers when the stepfather's guilty conscience prompts him to make a touching confession to the ghost of the boy's dead brother, who has returned, presumably to demand perhaps a proper burial. Of course, this lingering specter haunts not only the stepfather's conscience but also the boy who has recurring dreams of his brother. Deleuze states that "the affection-image is the close-up, and the close-up is the face" (Cinema 1, 87). In the film, the stepfather takes to reciting monologues to himself late into the night. While at first these scenes might appear to indicate that he has a mental disorder, it becomes clear that he is addressing an invisible figure, the ghost of the stepson he killed. A close-up image of the step-father's face displays helplessness, repentance, and remorse. We realize that he is deeply troubled by his anxiety-filled, miserable existence, with the added stress of a new baby and a low-paying job that does not enable him to support his family.

As for the boy's four portraits, they not only indicate the important events in his life, but also reflect the creative activity of painting. To Deleuze, painting has two figures of the face and he states,

In painting, the techniques of the portrait have accustomed us to these two poles of the face. Sometimes painting grasps the face as an outline, by an encircling line which traces the nose, the mouth, the edge of the eyelids, and even the beard and the cap: It is a surface of faceification. Sometimes, however, it works through dispersed features taken globally; fragmentary and broken lines which indicate here the quivering of the lips, there the brilliance of a look, and which involve a content which to a greater or lesser extent rebels against the outline: These are the traits of faceicity. (Cinema 1, 88)

Deleuze theories involve concepts of duality that should not be understood as the binary opposition of Hegelian dialectics. For Deleuze, painting's "faceification" corresponds to the concrete face, whereas "faceicity" refers to the intensity of affects and percepts of an imaginary face. Images emphasizing the latter pole of the face may appear blurred and indistinct. The boy's portraits, drawn in pencil, have features of both the concrete face and the indistinct one. The importance of these portraits-his father's face, the penis of his scoundrel friend, the missing brother walking along the riverbank-as affection-images is that they are the crucial events in the boy's life, forcing him to slide into the turbulent path of becoming. His attitude towards these events is detached, as if he has purposely situated himself outside of these events. The images in these portraits present his world as a consecutive series of crucial events in his life. Who is he? Why did he have to 
be born into such a life? Why did his father have to die? Why must his mother abandon him and his brother disappear? Why did his scoundrel friend have to show his penis in the public toilet? In fact, the fourth portrait, the boy's self-portrait, still remains unknown and unrealized because the film ends before the boy has drawn it. The film's open ending suggests different possibilities for the boy to actualize the chaotic forces of the virtual in his mind. Thus, to the viewers, the fourth portrait exists in the virtual state; the fourth portrait stays in chaos, full of the intensities of his mind's affects and precepts, all rendered as the empty face of the self-portrait.

\section{Event and Time as Specters}

The film never shares with the audience whether the boy succeeds in drawing his own self-portrait; we never know if his would-be self-portrait is an example of faceification or of faceicity. The ending of the movie introduces doubts, suspense, and the unknown. Yet, to create his self-portrait, the boy must confront not only the chaos of the world in which he lives but also the virtual chaos in his mind. Indeed, the final scene ends with the boy's looking into the mirror and gradually closing his eyes unable to draw anything on his blank sheet of the paper. The scene arouses a great suspense in the viewers, preparing us for an unwelcome encounter with the anxiety-ridden void we often confront when we are unable to solve the trickery-stricken conditions of life. Perhaps, a boy of such a young age would (or would not) think of another condition to be born into, one with a different family that would structure a different mode of life for him. Or perhaps, he could not even think of anything, leaving his mind in a state of emptiness. Freudian psychoanalysis tries to explain our destiny as indeed structured by our unconscious desire; even Lacanian psychoanalysis describes the unconscious subject that sets up the trick paving the path for our destiny. Deleuze, however, analyzes the concept of I, with a central fracture in its pure form of the past that opens up infinitely the transcendental field, demonstrating an ontological enigma that remains forever a secret: our self-knowledge regarding the purpose of existence itself. Perhaps the answers to our questions are untimely, as the director has left a certain "void" at the end, providing no solid answers to the condition of life.

In The Logic of Sense, Deleuze cites a line from Joe Bousquet’s stoic sense of ethics: "My wound existed before me, I was born to embody it” (148). This statement seems to suggest that the events operate within us, and we are just to fulfill the unnamable operator's mission within its onto-virtual significance. In Difference and Repetition, Deleuze tries to revise and redefine the notion of the death drive in terms of the three asymmetrical syntheses of time. This analysis corresponds to, if not exactly, a similar discussion of time-Chronos and Aions in The Logic of Sense as well as the notion of duration in Bergsonism. Indeed, the past itself functions like a haunting specter in this movie: The boy is haunted by his father's death, the mother's abandonment, and his own brother's disappearance; the stepfather is haunted by his guilty conscience for killing his stepson accidentally; the mother is haunted by her broken dream of searching for a better life in Taiwan; the old workman at school is haunted by his "real" homeland in China and wants to return to this faraway land. These circumstances clearly indicate that the past preserves itself in the present moment.

In Bergsonism, Deleuze states that the Bergsonian notion of time as duration is better defined as coexistence than as succession (60); in other words, the past coexists with the present. "The idea of a contemporaneity of the present and the past has one final consequence. Not only does the past coexist with the present that has been, but, as it preserves itself in itself (while the present passes), it is the whole, integral past: It is all our past, which coexists with each present” (61). The past that exists in disappearance belongs to ontology and it is contemporaneous with the present. In other words, the past preserves itself in the present and 
the present has always been haunted by the past. Thus, ontology has become hauntology, and Derrida in his book Specters of Marx claims that hauntology precedes ontology. What if haunting is the constitutive structural problem in which the specter of the past has to begin by returning itself again and again in different forms? We all unknowingly become the haunted subjects. Given the circumstances, the images actualized in the brain-screen have their own onto-hauntological status.

One scene in the movie stands out in this regard. The step father tries to communicate with Hsiao-Hsiang about avoiding divulgence of the family secrets because the house has been haunted by the undead specter of the past event. When the step father feels that this second step son, Hsiao-Hsiang, reacts in indifference and remains so detached, he suddenly flies into a great temper and almost tramples the boy to the floor with a loud push. This shocking scene allows us to imagine how the stepfather might have beaten his first step son to death. And he repeats it again, though in difference, the evil force to the boy. Repetition is the concept first discussed in Freud's essay, "Beyond the Pleasure Principle" outlining that the death drive follows its own pleasure, heading toward an inanimate state of life. In the Lacanian Seminar VII, Lacan explains that the death drive returns to the Lost Thing/the Maternal Object in the unconscious as if this returning path holds a secret jouissance for its sublime mission. To Deleuze, in Difference and Repetition, the concept of repetition itself indicates a difference. Perhaps, the most mysterious force within the subject is the virtual power as the eternal return within the secret ontology, which repeats in difference. The search for the original being/self could be a labor in vain because the origin is an unrecognizable "difference;" to Deleuze, the death instinct, not in the material model, "may be understood in relation to masks and costumes. Repetition is truly that which disguises itself in constituting itself, that which constitutes itself only by disguising itself” (Difference and Repetition, 17). Although the step father shows a strong sense of remorse for having killed his step son, he could not actually control his own quick temper when the second step son fails to obey his orders. In his confession scene, he demonstrates that he is deeply plagued by his conscience while talking to the first step son who has returned as a haunting ghost in the house. He is not consistently evil although his true self oftentimes remains "unnamable" to himself.

It seems that the idea of a death instinct must be understood in terms of three paradoxical and complementary requirements: to give repetition an original, positive principle, but also an autonomous disguising power; and finally, to give it an immanent meaning in which terror is closely mingled with the movement of selection and freedom. (Difference and Repetition, 19)

Contrary to what we might expect, what is affirmed repeats. In fact, as Deleuze explains it, repetition in difference in fact may not just create pleasure but displeasure as well. When Joe Bousquet explains his unfortunate existence, he embodies a pre-existing wound and even negatively embraces its "splendor" and "brightness" from an alternative perspective (The Logic of Sense, 149). As Deleuze states "The event is not what occurs (an accident), it is rather inside what occurs, the purely expressed" (149). What occurs inside the event is the untainted expression of the pure form of time with its eternal return in difference. Every event has a double structure: On one level, there is the present moment of actualizing the virtual event embodied in a state of affairs; on another level, the future and the past, which have their pre-individual, impersonal state of affairs, have been asymmetrically contracted at the present moment in the actualized event (151).

For example, for the boy in the movie, Hsiao-Hsiang, "paternal figures" successively fall into serial images of impotence: His own father, the step father, and the workman at school, all come with a sense of guilt. 
His own father has a frustrating relationship with his mother; the stepfather kills his brother; the workman leads a life of poverty always searching for left-behind objects in ruined buildings. Hsiao-Hsiang, feeling abandoned, exists like someone with a missing leg in a metaphorical sense. He seems to be condemned to lead a wandering life from the death of his own father to the misfortune of his step father, although the poetic images flowing through the cinematic consciousness created by the director's aesthetics reduce the misery into a becoming process experienced by a nomadic subject. To Deleuze, the pure form of time, the pure past, belongs to the pre-individual and impersonal, bearing witness to the subject's secrecy of ontological being, which issues a series of events. Does the boy in the movie have to be "condemned" to live with impotent father figures that have already partially expressed his ontological being? Would he have to exist like a nomadic schizo, ${ }^{5}$ due to an event that partially actualized his virtual being?

In other words, time itself is an ontological event. There are three synthesis of time interpreted by Deleuze:

The first synthesis, that of habit, constituted time as a living present by means of a passive foundation on which past and future depended. The second synthesis, that of memory, constituted time as a pure past, from the point of view of a ground which causes the passing of one present and the arrival of another. In the third synthesis, however, the present is no more than an actor, an author, an agent destined to be effaced; while the past is no more than a condition operating by default. (Difference and Repetition, 93-94)

This triadic structure of time demonstrates its inherently-constitutive unknown as difference in the pure form of the past. It is true that "the past itself is repetition by default, and it prepares this other repetition constituted by the metamorphosis in the present" (90). Metamorphosis suggests disguises and differences in the serial events actualized in the present, which remains "unknown" or "unrecognizable" as we encounter something puzzling or enigmatic. Indeed, the order of time - the past, the present, and the future-has inherently unequal, asymmetrical distributions: "the caesura, along with the before and after which it ordains once and for all, constitutes the fracture in the I" (89). In other words, time itself is out of joint in the concept of I, as if there is a groundless ground within the self that introduces a disruption, a central collapse, or a fractured dimension that forever remains disturbing and enigmatic. Perhaps this "something beyond" or outside is where the death drive wishes to return and thus it creates repetition in displeasure.

Even in psychoanalysis, Freud used the concept of "screen memory" to indicate that the original scene happened in the past and would not be entirely restored: It is not possible to piece together the fragmented images into a wholeness of what actually happened. Thus, what occurs on the brain screen as a stream of memory remains a form of "screen memory" which suggests that it could cover up something and fail to totally reveal what truly happened. Obviously, it is not possible to remember every detail of a past event; to recall a past event would inevitably fall into the stigma of unreliable narrative. By the same token, to Bergson, imagination is part of "memory." In Matter and Memory, he elucidates on two kinds of memories: one that repeats, like habit, and the other that can only be invented, like imagination. Because some memories cannot be repeated but are lost in the pure past, "imagination” fills the resulting gap or void. As Bergson puts it, "To call up the past in the form of an image, we must be able to withdraw ourselves from the action of the moment; we must have the power to value the useless; we must have the will to dream” (Matter and Memory, 83). Thus, to dream and to make a great leap into the past is to imagine the fragmented images of the past, which could also be mistaken for "the true memory." 
Returning to the characters in the movie, the step-father obviously has offered two different versions of stories to the policeman regarding the missing child (the step-son whom he beat to death). The house has been haunted by the past and even the ghost of the dead child has returned to haunt them. This deep sense of guilt is the negative affect that continually corrodes his conscience. Of course, the step-father's report to the policeman about the missing child is intended to cover up the whole truth, but his guilty conscience continues to punish him. He edits his memories of the past and substitutes memories that he has deliberately fabricated. His confession-scene is quite a disturbing moment with the affection-image at midnight, talking to the ghost of the dead child. We the viewers of course cannot actually know if this confession is based on the constructed narrative or if it reveals the true events of the past as he experiences them on his brain-screen. To the director, all narratives remain questionable; they exist like "the screen memory" that Freud described or Deleuze's central fracture in the concept of I. In this sense, I have already become "an other."

All these images - the brain screen, cinematic screen, and the world-screen-have contributed to the multi-layered juxtapositions of images studies in Deleuze's two books on the cinema. The cinematic term of "montage" that refers to the art of editing or cutting, presents the construction of visual images projected onto the screen. As a thought-screen, the brain has a similar function within its own logic of memories-editing and creative images-cutting, something Bergson would call “imagination.” In Cinema 2, Deleuze states,

The identity of world and brain, the automaton, does not form of a whole, but rather a limit, a membrance which puts an outside and an inside in contact, makes them present to each other, confronts them or makes them clash. The inside is psychology, the past, involution, a whole psychology of depths which excavate the brain. The outside is the cosmology of galaxies, the future, evolution, a whole supernatural which makes the world explode. The two forces are forces of death which embrace, are ultimately exchanged and become ultimately indiscernible. (Cinema 2, 206)

Consequently, the brain-screen and the world-screen are inevitably blended into each other and remain indistinguishable. The image-thought in the brain-screen is not just "memory” but "imagination" as well.

Yet, Bergson's retrieval of the lost memory by means of "imagination” is not identical with Deleuze's notion of creativity, even though we think the creators use "imagination" to create something out of chaos. Obviously, the director would not entirely use his past memory to conduct the creative art of films. In this sense, Deleuze denies that creativity is entirely based on "memory as imagination.” In What Is Philosophy, Deleuze makes the following statement:

It is true that every work of art is a monument, but here the monument is not something commemorating a past; it is a bloc of present sensations that owe their preservation only to themselves and that provide the event with the compound that celebrates it. The monument's action is not memory but fabulation. We write not with childhood memories but through blocs of childhood that are the becoming-child of the present. (What Is Philosophy? 168)

When it comes to the virtual forces of affects actualized out of chaos in terms of creative act as chaoids (art, philosophy, and science), we must not confuse the memory-images with the virtual forces of affects actualized as the images in our consciousness - even though these two kinds of images can remain indistinct from one another. Moreover, in Cinema 2, Deleuze writes the following:

We no longer believe in a whole as interiority of thought—even an open one; we believe in a force from the outside which hollows itself out, grabs us, and attracts the inside. We no longer believe in an association of images—even crossing voids; we believe in a break force from the outside which hollows itself out, grabs us, and attracts the inside. We no longer believe in an association of images_even crossing voids; we believe in breaks which take on an absolute value and subordinate all associations. (Cinema 2, 212) 
In other words, recollection in some circumstances corresponds to a form of imaginary construction. In fact, when we see the film, we seldom question if the director is making this film based on his memory or fabrication. Cinematic images, even in documentary films, fall into the intertwined world between creative imagination and reality; in any particular case, what matters is not the question of "the represented fact" but the proper presentation of "universal truth." The implication is not that we should remain suspicious of the director's cinematic world showing true aspects of the broken family in remote areas; rather, we should question how he presents his values of life through the aesthetically-fabricated images of cinematic consciousness.

The director arranges the step father's confession scene by means of affection-images, in which the narrative staged by the step father demonstrates the normal moral infliction of guilty conscience. Is it true or not? Is his explanation simply a simulation of conjectured narratives since the ghost, the specter, keeps haunting the house? Perhaps, the rather sensible confession is a way for the stepfather to simulate "a ritual of confession" to drive away the ghost and to dissipate the evil specter in the house. Deleuze states, "In the first place, the cinematographic image becomes a direct presentation of time, according to non-commensurable relations and irrational cuts. In the second place, this time-image puts thought into contact with an unthought, the unsummonable, the inexplicable, the undecidable, the incommensurable" (Cinema 2, 214). It seems that the time-image is a kind of cerebral game or virtual "film" in his brain about past events based on his narrative account; his disturbing sense of self evolves in his thought-images of communicating with the fractured I, part of which belongs to chaos.

Is the step father an evil man? After the perhaps simulated scene of confession while talking to the haunting ghost in the dark corner, the stepfather shows his bad temper again and directs it against Hsiao-Hsiang after a second round of the police questioning. He tells the boy not to divulge the family's secret to others, but the boy retorts that the family is not his, but the stepfather's. This hostility toward the stepfather, combined with the latter's repeated violent outbursts, suggests that the man has been violent toward both of his stepsons and that his confession may have been more truth than delirium. The stepfather is trapped in a double impossibility: the impossibility of correcting the mistakes of the past event and the impossibility of recreating a new mode of life. This repetition of the violent events resembles a curse on the soul. It is similar to the boy's willingness to stand up to the authority figures including the step-father and the woman teacher at school. It indicates that he is not afraid to confront oppressive power and suffer the potential consequences. With this repetitious phenomenon, it is the death drive with its own persistent will beyond the pleasure principle that comes into play here. It seems that there exists great secrecy in the soul that brings the repetitious events to one's life; it is the death mark that has already been imprinted in the unconscious. It also indicates an addictive jouissance or the dark enjoyment of a certain unnamable imperative. The death drive is a transcendental principle toward a sublime idea of the virtual, operating in the repetition of difference. "Time signifies a fault or a fracture in the $I$ and a passivity in the self, and the correlation between the passive self and the fractured $I$ constitutes the discovery of the transcendental..." (Difference and Repetition, 86). The characters in the films feel not only marginalized in society's structural inequality, but also trapped by their own mysteriously unknown forces beyond themselves. Perhaps, the director, Meng-Hung Chung, purposely leaves the fourth portrait empty and unnamable at the end, because it is the most difficult moment to draw this incomplete but potential image of "the fractured I." When the boy looks into the mirror and sees himself at the end of the movie, what image of thought and the sense of self are occurring in his mind? This affection-image at the end shows that he feels the 
disturbing void of the unknown which leads to a precarious life; the fourth portrait at the end becomes an empty-faced self-portrait.

\section{Notes}

1. Also called post-New Cinema or the Second New Wave. All of these are designations for the new direction of cinema between 1990 and 2010, following the Taiwanese "New Wave" of the 1980s.

2. Parking (2008) won Meng-Hung Chung the best director award both at the Taipei Film festival and at the Istanbul Independent Film festival in 2008. It was the representative film for the opening show in the 45th Golden Horse Film Festival in 2008.

3. The Fourth Portrait (2010) received awards for the best director and also the best annual Taiwanese film at the 47th Golden Horse Film Festival; it received the best film at the 13th Taipei film festival. It was shown in film festivals in Switzerland, Canada, Japan, South Korea, and Moscow.

4. Soul (2013) brought Meng-Hung Chung a best director nomination at the Golden Horse Film Festival. As a representative film in the opening show at the 16th Taipei Film Festival, it won the best sound effects award at the 50th Golden Horse Film Festival and Wang Yu, won the best actor for its leading male role at the16th Taipei film festival.

5. A schizo, according to psychoanalytic understanding, is an individual rendered pathologically incapable of using his/her rational faculties to think logically; this person's language therefore remains outside the social context. Yet, in the social revolutionary context, especially in the more Deleuzian-Guattarian affirmative sense, the notion of being a schizo in Anti-Oedipus means resisting identification with ones' social role (because Deleuze and Guattari think that the rigid social system is the major culprit in pathologizing the human mind; illness does not come from the immanence which is, in the conventional belief of psychiatric systems, has the secrecy of the mental illness). A schizo in Anti-Oedipus is the one who is anti-ego and anti-Oedipus; a schizo is a marginalized being working with his/her own immanent logic of the desiring machine, wandering alone in accordance with his/her own intensities of affects within the immanence which could be a great power to break through the social constraints. Perhaps one might consider the image of a wandering schizo inappropriate for depicting a boy in a film, particularly since his broken life and marginalized existence has been thrust upon him. In the Deleuzian-Guattarian context, the schizo is revolutionary, voluntarily creating a new mode of life and resisting to the social oppression. Although, these characters are not revolutionary types, their form of life is nomadic and at odds with the world. Obviously, the boy is condemned to feel free to be a nomadic schizo in his wandering life.

\section{Works Cited}

Bergson, Henri. Matter and Memory. New York: Zone Books, 1988.

Deleuze, Gilles and Félix Guattari. Anti-Oedipus: Capitalism and Schizophrenia. Trans. Robert Hurley, Mark Seem, and Helen R. Lane. New York: The Viking Press, 1977.

---. A Thousand Plateaus: Capitalism and Schizophrenia. Trans. Brian Massumi. Minnespolis: U of Minnesota P, 1987.

---. What Is Philosophy? Trans. Graham Burchell and Hugh Tomlinson. London: Verso, 1994.

Deleuze, Gilles. Foucault. Trans. Seán Hand. Minneapolis: U of Minnesota P, 1988.

---. Bergsonism. New York: Zone Book, 1988b.

---. The Logic of Sense. Trans. Mark Lester and Charles Stivale. Ed. Constantin V. Boundas. New York: Columbia UP, 1990.

---. Kant’s Critical Philosophy. Minneapolis: U of Minnesota P, 1990b.

---. Cinema 1. Trans. Hugh Tomlinson and Barbara Habberjam. Minneapolis: U of Minnesota P, 1991.

---. Cinema 2. Trans. Hugh Tomlinson and Robert Galeta. Minneapolis: U of Minnesota P, 1991.

---. Negotiations. Trans. Martin Joughin. New York: Columbia UP, 1995.

---. Essays Critical and Clinical. Trans. Daniel W. Smith and Michael A. Greco. London: Verso, 1998.

---. Pure Immanence: Essays on a Life. Trans. Anne Boyman. New York: Zone Books, 2001.

Deleuze, Gilles and Claire Parnet. Dialogues. Trans. Hugh Tomlinson. New York: Columbia UP, 1987.

---. Dialogues II. Trans. Hugh Tomlinson and Barbara Habberjam. New York: Continuum, 1977.

Flaxman, Gregory. The Brain Is the Screen: Deleuze and the Philosophy of Cinema. Minneapolis: U of Minnesota P, 2000.

Shaw, Spencer. Film Consciousness: From Phenomenology to Deleuze. Jefferson: McFarland, 2008. 